\title{
Ethnobotanical survey of plants used as repellents against housefly, Musca domestica L. (Diptera: Muscidae) in Budondo Subcounty, Jinja District, Uganda
}

\author{
Kalori Baana ${ }^{1}$, Harriet Angwech ${ }^{1}$ and Geoffrey Maxwell Malinga ${ }^{1,2^{*}}$
}

\begin{abstract}
Background: The housefly, Musca domestica L., is a major public health and domestic pest that spoils food and causes irritation and is a vector of many infectious disease pathogens of medical and veterinary importance. Currently, its control relies largely on chemical pesticides. However, the adverse health and environmental effects of pesticides, risk of development of insect resistance, and bioaccumulation through the food chain emphasize the need to search for environmentally friendly alternatives. This study aimed at documenting traditional knowledge about plants used as repellents against the houseflies by the people of Budondo Subcounty, Uganda.

Methods: An ethnobotanical survey was conducted between November 2016 and June 2017. A total of 372 household members were interviewed on knowledge and use of traditional insect repellents, through face-toface interviews guided by semi-structured questionnaires administered in nine villages in Budondo Subcounty.

Results: Overall, only $24.5 \%$ of the respondents had ample knowledge about insect repellent plants. A chi-square analysis shows a significant association between respondents' knowledge of insect repellent plants and age, educational status, occupation, religion, and marital status although not with gender. Overall, eight plants from seven families and eight genera were mentioned as repellents. The growth forms encountered were tree, shrub, and herb. Plants that were commonly mentioned by respondents were Cupressus sempervirens L. (16.9\%), followed by Lantana camara L.(16.1\%), Eucalyptus globulus Labill. (11.0\%), Carica papaya L. (8.6\%), Cymbopogon citratus (de Candolle) Stapf (4.3\%), Mentha $\times$ piperita L. (2.4\%), Azadirachta indica A. Juss (2.2\%), and Ocimum kilimandscharicum Gürke (0.8\%) in descending order. Leaves were the most commonly used plant part (76.9\%), followed by the stem/bark (19.8\%), flowers (2.2\%), and root (1.1\%). Burning of the plant materials in order to generate smoke was the most popular method of application.

Conclusions: This study has shown that there are many locally available plants in use by the people of Budondo Subcounty with potency for repelling houseflies. Further studies are needed to identify bioactive compounds responsible for the repellent activity in the different species which could be promoted as sustainable housefly control tools in these remotely located communities of Budondo. Furthermore, studies on the efficacy of these repellent plants or plant parts and their potential toxicological properties should be considered a priority.
\end{abstract}

Keywords: Ethnobotanical knowledge, Insects, Uganda, Repellent plants

\footnotetext{
* Correspondence: malingageoffrey@yahoo.com

${ }^{1}$ Department of Biology, Faculty of Science, Gulu University, P.O. Box 166, Gulu, Uganda

${ }^{2}$ Department of Environmental and Biological Sciences, University of Eastern Finland, P.O. Box 111, 80101 Joensuu, Finland
}

(c) The Author(s). 2018 Open Access This article is distributed under the terms of the Creative Commons Attribution 4.0 International License (http://creativecommons.org/licenses/by/4.0/), which permits unrestricted use, distribution, and reproduction in any medium, provided you give appropriate credit to the original author(s) and the source, provide a link to the Creative Commons license, and indicate if changes were made. The Creative Commons Public Domain Dedication waiver (http://creativecommons.org/publicdomain/zero/1.0/) applies to the data made available in this article, unless otherwise stated. 


\section{Background}

The housefly, Musca domestica L. (Diptera: Insecta: Muscidae), is a notorious cosmopolitan pest which causes nuisance and irritation and spoils food and is a vector for many pathogenic organisms that affect humans and livestock [1]. According to Bulter [2], houseflies are vectors because of their coprophagous, indiscriminate, and synanthropic feeding habits. The transfer of pathogens occurs through dislodgement from their hairy body parts and from fly feeding and regurgitation or defecation [3, 4]. Although they do not bite, the fly transmits more than 100 human and non-human animal diseases including bacterial infections like salmonellosis, anthrax, shigellosis, typhoid fever, tuberculosis, cholera and diarrhea, and protozoan infections such as amoebic dysentery [5, 6]. They also transmit eggs of helminths such as pinworms, roundworms, hook worms, and tapeworms as well as viral infections, rickettsial infections, and in some cases, life-threatening Escherichia coli [2]. Besides, it is also responsible for transmitting pathogens which cause trachoma and conjunctiva, both of which are estimated to cause approximately 6 million cases of childhood blindness annually worldwide [7]. There are also indications that houseflies are potential carriers of avian influenza flu virus posing threats to humans $[8,9]$.

However, despite being a major vector for several human and animal diseases, the control aspects of the housefly, Musca domestica L., is often neglected [10]. Currently, the control of houseflies relies largely on chemical pesticides. However, the adverse health and environmental effects of pesticides, high cost, risk of development of insect resistance, and bioaccumulation through the food chain [11] emphasize the need to search for low-cost, environmentally friendly alternatives that can complement existing interventions. For developing countries like Uganda whose inhabitants and health and sanitation standards are poor, the use of repellents is the only viable protection against vectors in their contact [12]. In the past few years, many researchers have started exploring the potentials of locally based botanicals against insect pests $[12,13]$. Compared to synthetic compounds, plant-based repellents are less toxic [14], less costly, and easily accessible [15], and are still extensively used traditionally as an affordable control option against flies in different communities in Africa [15-17]. For example, in Ethiopia, Karunamoorthi et al. [16] documented nine insect repellent plants belonging to eight genera and families, with the most frequently mentioned being Boswellia papyrifera (Del.) Hochst, Croton macrostachyus Del., and Melia azedarach L. In a rural community of Cameroon, the plant species most commonly used as insect repellents were Saccharum officinarum and Ocimum basilicum [18]. In
Cegere Subcounty, northern Uganda, Anywar et al. [19] reported four plant species: Ocimum forsskaolii Benth, Manihot esculenta Crantz, Musa sp., and Gossypium hirsutum L. that are burnt in the house to produce smoke to repel mosquitoes. Unfortunately, however, this indigenous knowledge is being lost as the elderly people die before passing it to younger generations [20]. To ensure the conservation and sustainable utilization of these biological resources, documentation of indigenous knowledge through ethnobotanical studies is urgently needed. So far, studies on the traditional use of ethnobotanical plants as repellents against houseflies and other insects have not have been conducted in Budondo Subcounty. This study was conducted to assess the respondents' knowledge and to document plants that are traditionally used by the communities of Budondo Subcounty, Jinja District, Uganda, in repelling houseflies/insects.

\section{Methods \\ Study area}

This study was conducted in nine villages of Kibibi, Ivunamba, Nawangoma, Buwagi, Kagera, Kyomya, Bufula, Kivubuka, and Buyala B found in Budondo Subcounty, Jinja District, along the northern shores of Lake Victoria, approximately $81 \mathrm{~km}$ by road from Kampala $\left(00^{\circ} 25^{\prime}\right.$ $\left.24 \mathrm{~N}, 33^{\circ} 12^{\prime} 4 \mathrm{E}\right)$. The vegetation consists of grasslands, woodlands, thickets, and bushlands.

\section{Data collection}

The study was a cross-sectional descriptive survey and was conducted between November 2016 and June 2017. Data was collected through an ethnobotanical survey employing semi-structured interviews and guided openended questionnaires. The households (respondents) for the questionnaires were randomly selected using Krejcie and Morgan table [21]. The questionnaires were administered in Lusoga (the local language in the study area) to 372 local respondents randomly selected using household numbers from nine villages. The household heads who were found at or near their homes at the time of the interview were interviewed, and the researcher did not make return visits to household heads who were not present at the time of administering the questionnaires. This ensured that the individuals who were already interviewed did not influence the views of subsequent respondents. During the interview, the respondents were presented with housefly specimen to guide their responses. The questions asked included the sociodemographic status, the local names of the plants used to repel the fly, part(s) of the plant harvested, and methods of preparation and administration. This was followed by a village walk to verify the plants mentioned and to collect voucher specimen from the plants claimed to have repellent activity (Fig. 1). Key informant interviews and 


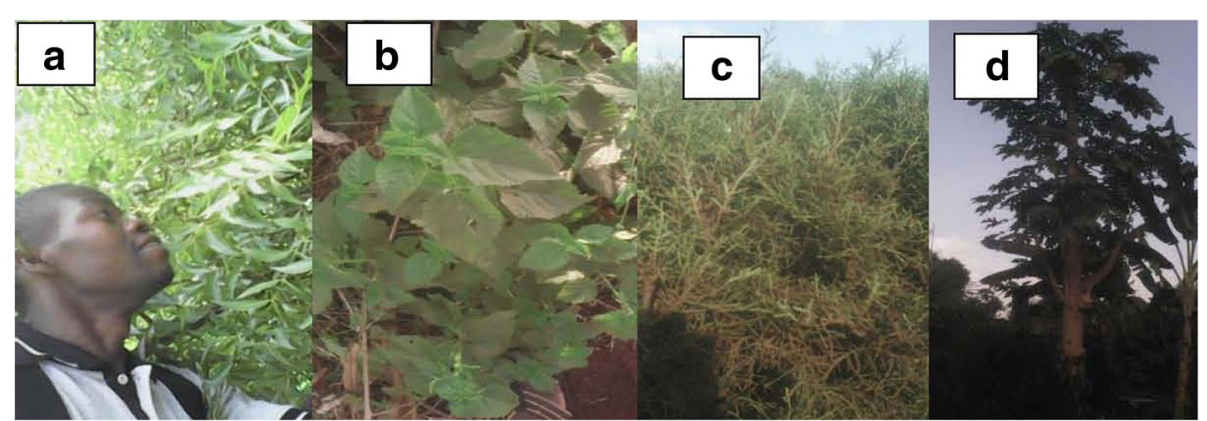

Fig. 1 Some of the plants identified as a repellent against housefly, Musca domestica L., during a village walk in Nawangoma Village, Budondo subcounty. a Azadirachta indica A. Juss. b Lantana camara L. c Cupressus sempervirens L. d Carica papaya L.

focus group discussions were also conducted to validate the responses obtained from the questionnaires. All the plant materials mentioned by the respondents were identified in the field, and the correctness of the scientific names is checked using the online plant tropicos database [http://www.tropicos.org, accessed 12/06/2017]. Specimens were assigned voucher numbers at the Makerere University Herbarium.

\section{Data analysis}

Descriptive statistics using frequencies and percentages were used to summarize ethnobotanical data in Excel 2010. The association between respondents' knowledge with their gender, age, educational status, occupation, religion, and marital status was tested with chi-square analysis. Statistical analysis was carried out using SPSS version 23 at $5 \%$ level of significance $(P<0.05)$.

\section{Results}

\section{Socio-demographic characteristics of respondents}

The profile of the 372 respondents interviewed in this study is given in Table 1. They comprised 169 (46.5\%) males and 203 (53.5\%) females and were between the ages of 11 to 91 years (the majority were between 21 to 30 years old, Table 1). Most of the respondents (60.5\%) had a basic primary level education. Only 18 (4.8\%) of the interviewed respondents were formally employed (Table 1). The majority of respondents belonged to the mainstream religions and were mostly Catholics (26.9\%), Muslims (22.3\%), Anglican (21.2\%), and Pentecostals (20. $4 \%)$. The majority $(66.9 \%)$ of respondents were married. Overall, 24.5\% (91/372) of the respondents had knowledge about housefly/insect repellent plants (Table 1).

Traditional knowledge on housefly/insect repellent plants A chi-square analysis shows that there was no significant difference observed in the knowledge of the repellent plants between the gender $\left(\chi^{2}=1.274, \mathrm{df}=1, P\right.$ value $=0$. $256)$, but there was a significant association with age $\left(\chi^{2}=171.2, \mathrm{df}=6, P<0.001\right)$, education status $\left(\chi^{2}=28.7\right.$, $\mathrm{df}=5, P<0.001)$, occupation $\left(\chi^{2}=17.2, \mathrm{df}=3, P=0.001\right)$, religion $\left(X^{2}=29.5, \mathrm{df}=5, P<0.001\right)$, and marital status of respondents $\left(\chi^{2}=35.0, \mathrm{df}=1, P<0.001\right)$ (Table 2). The adults were more knowledgeable than the young ones (Table 2). The Catholics were more knowledgeable than the others.

\section{Plants and parts used as repellents}

A total of eight plants belonging to eight genera and seven families were reported to be commonly used as a repellent against houseflies in the study area (Table 3). The most commonly represented family was Lamiaceae which had two plants, while the others (Verbenaceae, Myrtaceae, Cupressaceae, Caricaceae, Meliaceae, and Poaceae) consisted of a single species each (Table 3). The most commonly used plant was Cupressus sempervirens $\mathrm{L}$. (mentioned by $16.9 \%$ of respondents who had knowledge about the plants), followed by Lantana camara L. (16.1\%), Eucalyptus globulus Labill. (11.0\%), Carica papaya L. (8.6\%), Cymbopogon citratus (de Candolle) Stapf (4.3\%), Mentha $\times$ piperita L. (2.4\%), and Azadirachta indica A. Juss (2.2\%), and Ocimum kilimandscharicum Güerke was the least mentioned (1.1\%). The commonest life forms encountered were tree, shrub, and herb. The leaves were the most common plant parts used $(76.9 \%)$ followed by the stem/bark (19.8\%) while the flowers $(2.2 \%)$ and roots (1.1\%) were the least used (Table 3).

\section{Modes of preparation and administration of repellents}

The respondents employed a variety of methods to prepare and administer repellent plants (Table 3) The plant materials were used by hanging it in the room while fresh or throwing dry leaves in the garbage collection areas (e.g., C. sempervirens); burning fresh or dry leaves, stem, flowers, or root to generate smoke (L. camara, $C$. sempervirens, A.indica, C.citratus, Metha $\times$ piperita, $O$. kilimandscharicum, and E. globulus); crushing fresh parts to obtain extract and applying it on the skin/exposed parts of the body (e.g., for C.papaya and A. indica, Table 3) 
Table 1 Socio-demographic characteristics of the respondents $(n=372)$

\begin{tabular}{|c|c|c|}
\hline Characteristics & Frequency & Percent \\
\hline \multicolumn{3}{|l|}{ Gender } \\
\hline Male & 169 & 46.5 \\
\hline Female & 203 & 53.5 \\
\hline \multicolumn{3}{|l|}{ Age of respondents (years) } \\
\hline $11-20$ & 50 & 13.4 \\
\hline $21-30$ & 143 & 38.4 \\
\hline $31-40$ & 78 & 20.9 \\
\hline $41-50$ & 47 & 12.6 \\
\hline $51-60$ & 24 & 6.5 \\
\hline Above 60 & 30 & 8.1 \\
\hline \multicolumn{3}{|l|}{ Educational status } \\
\hline None & 24 & 6.5 \\
\hline Primary & 225 & 60.5 \\
\hline Ordinary secondary & 55 & 14.8 \\
\hline Advanced secondary & 39 & 10.5 \\
\hline Post-secondary & 29 & 7.8 \\
\hline \multicolumn{3}{|l|}{ Occupation } \\
\hline Peasant (small farmers) & 237 & 63.7 \\
\hline Trader & 58 & 15.6 \\
\hline Civil servant & 18 & 4.8 \\
\hline Student & 59 & 15.9 \\
\hline \multicolumn{3}{|l|}{ Religion } \\
\hline Catholic & 100 & 26.9 \\
\hline Muslim & 83 & 22.3 \\
\hline Anglican & 79 & 21.2 \\
\hline Pentecostal & 76 & 20.4 \\
\hline Traditionalist & 7 & 1.9 \\
\hline Others & 27 & 7.3 \\
\hline \multicolumn{3}{|l|}{ Marital status } \\
\hline Single & 123 & 33.1 \\
\hline Married & 249 & 66.9 \\
\hline \multicolumn{3}{|c|}{ Knowledge on insect repellent plants } \\
\hline Yes & 91 & 24.5 \\
\hline No & 281 & 75.5 \\
\hline
\end{tabular}

, and tying them together to form a broom which are used for sweeping away flies from fresh fish and offals on display in the markets (e.g., C. sempervirens). Burning or smoldering fresh or dry plant materials in order to generate smoke was the most popular method of application. The plant parts were kept in the shade before they are smoked in the areas where they are required. The places where repellents were used included pit latrines, garbage collection areas, kitchens, fish stores, and markets areas where offal and fresh fish are sold. The respondents reported that the appropriate plant parts were collected when needed either by women or men and that there was no specific dose administered; the amount of plant material used depended on the number of flies in the area and the intensity of odor that each plant produces upon administration. Eight respondents reported that $C$. sempervirens was used to cover offal in the markets to prevent flies from accumulating on it. Two informants reported that they use the sap from young stems of $C$. papaya to spray to their livestock to prevent disturbance from flies and that the same sap is applied on the udder of the lactating cows to serve as a lubricant during milking and to repel flies after milking. During a focus group discussion, ten respondents aged 42 to 70 years mentioned fresh leaves of L. camara, E. globulus, C. citratus, and C. sempervirens as being smoked in kitchens during festival seasons to repel the flies that could be attracted by the smell of accumulated meat that has stayed overnight. These plants were also reported to be used during rainy seasons to reduce the dense population of the flies most especially where the food and fruit wastes are deposited.

\section{Discussion}

In the present study, eight plant species were reported to be used as repellents against Musca domestica L. by the local inhabitants in the study area. Overall, the number of plants reported in this study was low compared to those obtained in other ethnobotanical studies [16, 17]. Most of the plants reported, e.g., C.sempervirens, E.globulus, C.papaya, C.citratus, M. × piperita, A. indica, and O. kilimandscharicum, were not native to Budondo Subcounty, with the exception of L. camara. Most of the plants are cultivated at homes except $O$. kilimandscharicum and $L$. camara which are wild. Similar plants have also been previously reported as repellents against traditional insects in several other studies in Kenya [14, 22], Tanzania [23], and Ethiopia [16, 24]. The family Lamiaceae was the most represented insect repellent plant family as found also in an earlier study in Kenya by Kariuki et al. [22]. Lamiaceae is a highly diverse family with a rich source of essential oils which are volatile compounds with a strong odor [25]. The observed insect repellent attributes of these plants might be due to their chemical composition. For example, lemongrass (C. citratus), commonly cultivated around homes and whose scent resembles that of lemon, has been shown to contain essential volatile oils that can repel flies. L. camara has also been shown to contain a variety of terpenes and alkaloids that can effectively repel flies [26]. Meanwhile, the selection of $E$. globulus may due to its mint-smelling leaves. The bioactive compounds present in these leaves are said to be comparable to the active ingredients present in commercial insect repellents [27].

Our results also showed that only $24.5 \%$ of the respondents surveyed had knowledge about the housefly-repellent 
Table 2 Knowledge on housefly/insect repellent plants in relation with age, gender, educational status, religion, occupation and marital status of the respondents

\begin{tabular}{|c|c|c|c|c|c|}
\hline \multirow[t]{2}{*}{ Characteristics } & \multirow{2}{*}{$\begin{array}{l}\text { Total number of } \\
\text { respondents }\end{array}$} & \multicolumn{2}{|c|}{ Knowledge on insect repellent plants } & \multirow[t]{2}{*}{$x^{2}$} & \multirow[t]{2}{*}{$P$ value } \\
\hline & & No & Yes & & \\
\hline \multicolumn{6}{|l|}{ Gender } \\
\hline Male & 169 & 123 & 46 & \multirow[t]{2}{*}{$x^{2}=1.274, d f=1$} & \multirow[t]{2}{*}{$P=0.256$} \\
\hline Female & 203 & 158 & 45 & & \\
\hline \multicolumn{6}{|l|}{ Age (years) } \\
\hline $11-20$ & 50 & 47 & 3 & \multirow[t]{6}{*}{$x^{2}=171.2, d f=6$} & \multirow[t]{6}{*}{$P<0.001$} \\
\hline $21-30$ & 143 & 136 & 7 & & \\
\hline $31-40$ & 78 & 68 & 10 & & \\
\hline $41-50$ & 47 & 21 & 26 & & \\
\hline $51-60$ & 24 & 4 & 20 & & \\
\hline Above 60 & 30 & 5 & 25 & & \\
\hline \multicolumn{6}{|l|}{ Educational status } \\
\hline Illiterate & 24 & 8 & 16 & \multirow[t]{6}{*}{$x^{2}=28.7, d f=5$} & \multirow[t]{6}{*}{$P<0.001$} \\
\hline Primary & 225 & 174 & 51 & & \\
\hline Ordinary secondary & 55 & 46 & 9 & & \\
\hline Advanced secondary & 39 & 33 & 6 & & \\
\hline Certificate and diploma & 13 & 10 & 3 & & \\
\hline Degree & 16 & 6 & 10 & & \\
\hline \multicolumn{6}{|l|}{ Occupation } \\
\hline Peasant (small farmers) & 237 & 174 & 63 & \multirow[t]{4}{*}{$x^{2}=17.2, d f=3$} & \multirow[t]{4}{*}{$P=0.001$} \\
\hline Civil servant & 18 & 10 & 8 & & \\
\hline Trader/self-employed & 58 & 41 & 17 & & \\
\hline Student & 59 & 56 & 3 & & \\
\hline \multicolumn{6}{|l|}{ Religion } \\
\hline Catholic & 100 & 66 & 34 & \multirow[t]{6}{*}{$x^{2}=29.5, d f=5$} & \multirow[t]{6}{*}{$P<0.001$} \\
\hline Muslim & 83 & 62 & 21 & & \\
\hline Anglican & 79 & 62 & 14 & & \\
\hline Pentecostal & 76 & 68 & 8 & & \\
\hline Traditionalist & 7 & 1 & 6 & & \\
\hline Others & 27 & 19 & 8 & & \\
\hline \multicolumn{6}{|l|}{ Marital status } \\
\hline Single & 123 & 116 & 7 & \multirow[t]{2}{*}{$x^{2}=35.0, d f=1$} & \multirow[t]{2}{*}{$P<0.001$} \\
\hline Married & 249 & 165 & 84 & & \\
\hline
\end{tabular}

property of plants. This level of knowledge about insect repellents is poorer than in a study conducted in Ethiopia, in which $97.2 \%$ of the respondents had ample knowledge about traditional insect/mosquito repellent plants [16]. This finding is an indication that the indigenous knowledge is rapidly disappearing/eroding from the society. Our results also showed no significant difference in the knowledge of the repellent plants between gender as indicated also in a previous study conducted in Ethiopia with reference to gender and knowledge on insect repellent plants [28]. In contrast, Karunamoorthi and Hailu [24] found no significant association between respondents' knowledge and gender. These results suggest that the repellent plants are generally known by the members of the community irrespective of their sex. However, the selection of the plants seems to be homogenous among the respondents, indicating that the people of Budondo use almost the same plants to repel the flies. Furthermore, our results also showed a significant association between the respondents' knowledge on insect repellent plants and their age (Table 2). This can 


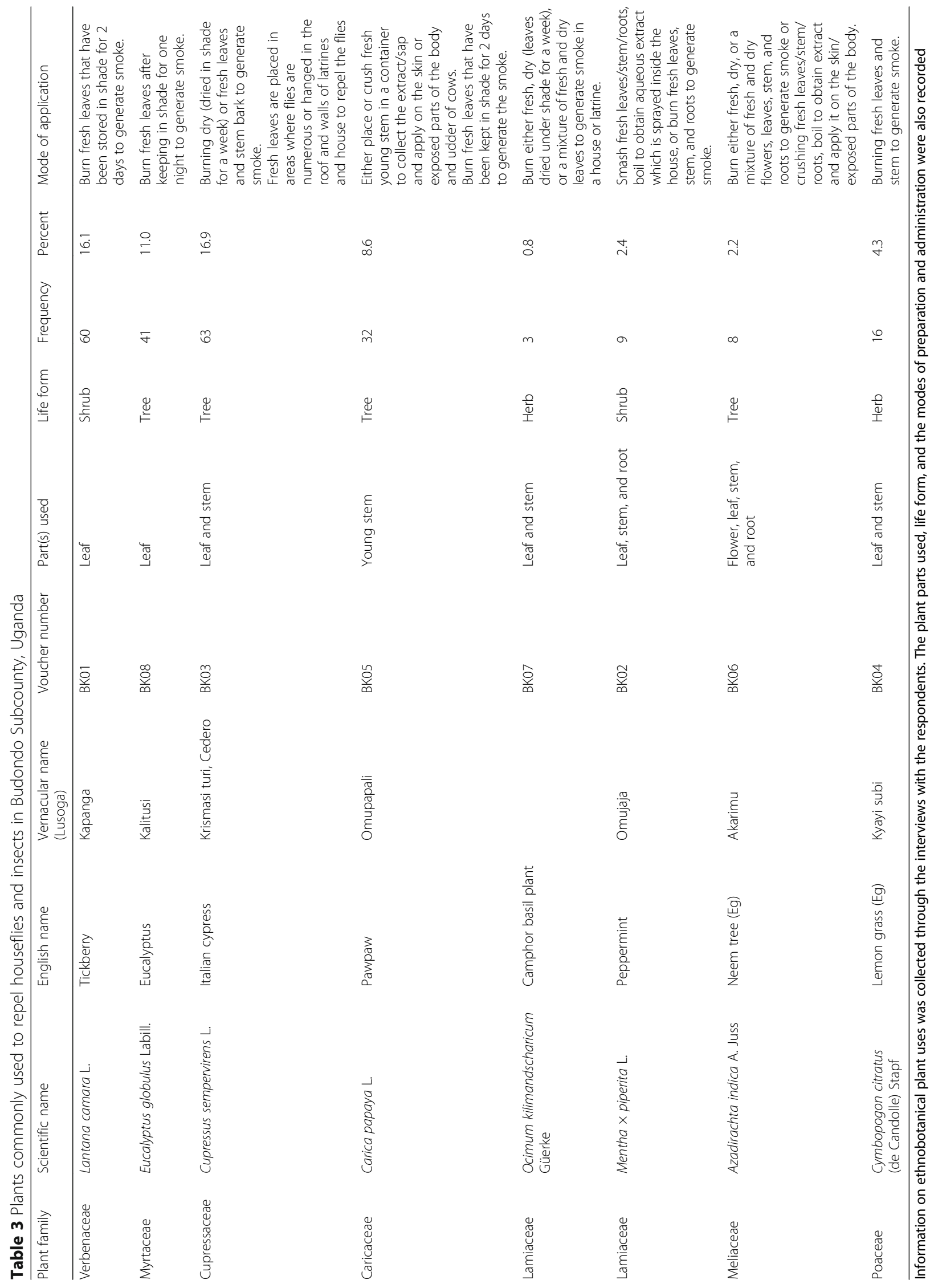


be explained by the fact that elderly people tend to have more knowledge about insect repellents than the young ones because of the frequent exposure to traditional repellent plants [16].

Burning of both fresh or dry leaves and stems to produce in-house smoke to repel the flies was the most favored mode of administration of these plants aligning with the claim of Pålsson and Jaenson [29] in Guinea Bissau which indicated that burning of plants might be effective in repelling flies. Similar results have also been reported in other studies in Kenya [22, 30] and Ethiopia [16] where burning of either fresh or dried repellent plants is one of the common practice to drive away biting insects. It is usually performed using the traditional charcoal stove during the day or in early evenings to repel the flies from dark areas. Although data is scarce on how repellent smokes work, the repellent activity of burned plants might be due to the release of specific volatile compounds (e.g., $\beta$-ocimene) created during combustion or from the plant materials themselves [23]. Besides smoking, C. sempervirens plants have been used by hanging it on the walls and roofs. In addition, spraying the crushed leaf (C.papaya), stem, and roots (A. indica and Metha $\times$ piperita) is also another practice. This finding is consistent with a previous study by Karunamoorthi et al. [16] in Ethiopia which indicates that hanging the leaves of repellent plants in the room and spraying the crushed extracts of repellents plants is a common practice.

Regarding the parts of the plants used for repelling houseflies, the results of the present study indicated that the communities preferentially used leaves, followed by stem/bark, flowers, and roots, and most of the respondents reported the use of fresh leaves. These findings are consistent with those of Youmsi et al. [31] who reported the leaf as the most commonly used repellent plant part. The preference for leaves could be due to the fact that leaves are readily available or that the bioactive compounds or secondary metabolites presumed to be responsible for repelling the flies are more concentrated in the leaves compared to other parts of the plants [31]. Furthermore, the high preference for leaves might result from the strong feeling by the community to preserve these plants. Compared to harvesting plant barks or gathering the whole plant which could cause the extinction of the species, the harvesting of leaves is relatively more sustainable since the plant can regrow new leaves easily, especially during the rainy seasons.

\section{Conclusion}

From this study, it was noted that there are many locally available plants in use by the people of Budondo Subcounty with potency for repelling houseflies. Cupressus sempervirens, Lantana camara, and Eucalyptus globulus were reported as the main repellents against housefly. We recommend further research on these plants to identify the bioactive compounds responsible for the repellent activity in the different species which could be extracted and formulated into useful bioproduct for controlling houseflies. Furthermore, studies on the efficacy of the repellent plants or plant parts and potential toxicological properties should be a priority.

\section{Acknowledgements}

The authors acknowledge the invaluable cooperation of all the respondents during the data collection.

\section{Availability of data and materials}

The data for this study may be availed upon request.

\section{Authors' contributions}

The study was designed and supervised by MGM. BK collected the data and identified the plant samples. MGM, AH, and BK contributed to the drafting and revision of the manuscript, and all authors read and approved the final version of the manuscript.

\section{Ethics approval and consent to participate}

This ethnobotanical survey was performed according to the current Uganda National Council of Science and Technology legislation and was approved by the Gulu University Ethical Review Committee. Permission to conduct the study in Budondo Subcounty was obtained from the subcounty administrators. Verbal pre-informed consent was sought from the study participants after explaining the purpose, expected benefits, and risks associated with the study. Prior to the study, permission from the local council chairpersons of each village was obtained.

\section{Competing interests}

The authors declare that they have no competing interests.

\section{Publisher's Note}

Springer Nature remains neutral with regard to jurisdictional claims in published maps and institutional affiliations.

Received: 18 December 2017 Accepted: 3 May 2018

Published online: 10 May 2018

\section{References}

1. Kumar P, Mishra S, Malik A, Satya S. Insecticidal evaluation of essential oils of Citrus sinensis L. (Myrtales: Myrtaceae) against housefly, Musca domestica L. (Diptera: Muscidae). Parasitol Res. 2012;110:1929-36.

2. Bulter FC, Garcia-Maruniak A, Meek F, Marunaik JE. Wild Florida house flies (Musca domestica) as carriers of pathogenic bacteria. Fla Entomol. 2010;93: 218-23.

3. Meerberg BG, Vermeer HM, Kijlstra M. Controlling of pathogen transmission by flies on organic pig farms. Outlook Agric. 2007;36:193-7.

4. Fotedar R. Vector potential of Musca domestica in transmission of Vibrio cholera in India. Acta Trop. 2001;78(1):31-4.

5. Umeche $\mathrm{N}$, Mandah LE. Musca domestica as carrier of intestinal helminths in Calabar, Nigeria. East Afr Med J. 1989;65(5):349-52.

6. Fotedar R, Banerjee U, Singh S, Shriniwus, Verma AK. The housefly (Musca domestica) as carrier of pathogenic microorganisms in a hospital environment. J Hosp Infect. 1992;20:209-15.

7. Malik A, Singh N, Satya S. Housefly (Musca domestica) a review of control strategies for a challenging pest. J Environ Sci Health. 2007;42:453-67.

8. Wanaratana S, Panyim S, Pakpinyo S. The potential of house flies to act as a vector of avian influenza subtype H5N1 under experimental conditions. Med Vet Entomol. 2011;25:58-63.

9. Wanaratana S, Amonsin A, Chaisingh A, Panyim S, Sasipreeyajan J, Pakpinyo S. Experimental assessment of houseflies as vectors in avian influenza subtype H5N1 transmission in chickens. Avian Dis. 2013;57(2):266-72. 
10. Kumar P, Mishra S, Malik A, Satya S. Housefly (Musca domestica L.) control potential of Cymbopogon citratus Stapf. (Poales: Poaceae) essential oil and monoterpenes (citral and 1,8-cineole). Parasitol Res. 2013;112(1):69-76.

11. Chauhan N, Malik A, Sharma S. Repellency potential of essential oils against housefly, Musca domestica L. Environ Sci Pollut Res Int. 2018;25(5):4707-14.

12. Pavela R, Benelli G. Ethnobotanical knowledge on botanical repellents employed in the African region against mosquito vectors - a review. Exp Parasitol. 2016;167:103-8.

13. Sharma PP, Pardeshi AB, Vijigiri D. Bioactivity of some medicinal plant extracts against Musca domestica L. J Ecobiotechnol. 2011;3(9):14-6.

14. Moore SJ, Lenglet A, Hill N. Plant-based insect repellents. In: Insect repellents: principles methods, and use. Boca Raton, Florida: CRC Press; 2006.

15. Mavundza EJ, Muharaj R, Finnie JF, Kabera G, Van Staden J. An ethnobotanical survey of mosquito repellent plants in uMkhanyakude district, KwaZulu-Natal province, South Africa. Aust J Pharm. 2011;137:1516-20.

16. Karunamoorthi K, llango K, Endale A. Ethnobotanical survey of knowledge and usage custom of traditional insect/mosquito repellent plants among the Ethiopian Oromo ethnic group. J Ethnopharmacol. 2009;125(2):224-9.

17. Karunamoorthi K, Tsehaye E. Ethnomedicinal knowledge, belief and selfreported practice of local inhabitants on traditional antimalarial plants and phytotheraphy. J Ethnopharmacol. 2012;141(1):143-50.

18. Ntonifor NN, Ngufor CA, Kimbi HK, Oben BO. Traditional use of indigenous mosquito-repellents to protect humans against mosquitoes and other insect bites in a rural community of Cameroon. East Afr Med J. 2006; 83(10):553-8.

19. Anywar G, Charlotte IEA, Klooster V, Byamukama R, Willcox M, Nalumasi PA, de Jong J, Rwaburindori P, Kiremire BT. Medicinal plants used in the treatment and prevention of malaria in Cegere Subcounty, northern Uganda. Ethnobot Res Appl. 2016;14:506-16.

20. Munthu C, Ayyapar M, Raja N, Ignacimuthu S. Medicinal plants used by traditional healers in Kancheepuran district of Tamil Nadu, India. J Ethnobiol Ethnomed. 2006;2:43.

21. Krejcie RV, Morgan DW. Determining sample size for research activities. Educ Psychol Meas. 1970;30:607-10

22. Kariuki JM, Kariuki ST, Muchiri DR, Njoka E. Field evaluation of naturally occurring mosquito repellents in Mt. Kenya region, Kenya. Int J Biodivers Conserv. 2016:8(2):55-9.

23. Kweka EJ, Mosha F, Lowassa A, Mahande AM, Kitau J, Matowa J, Mahande MJ, Massenga CP, Tenu F, Feston E, Lyatuu EE, Mboya MA, Mndeme R, Chuwa G, Temu EA. Ethnobotanical study of some of mosquito repellent plants in north-eastern Tanzania. Malar J. 2008;7:152. https:/doi.org/10.1186/ 1475-2875-7-152.

24. Karunamoorthi K, Hailu T. Insect repellent plants traditional usage practices in the Ethiopian malaria epidemic-prone setting: an ethnobotanical survey. J Ethnobiol Ethnomed. 2014;10:22.

25. Isman MB. Botanical insecticides, deterrants and repellents in modern agriculture in an increasingly regulated world. Annu Rev Entomol. 2006; 51:45-66.

26. Omolo MO, Okinyo D, Ndiege IO, Lwande W, Hassanali A. Fumigant toxicity of the essential oils of some African plants against Anopheles gambiae sensu stricto. Phytomedicine. 2005;12:241-6.

27. Moore SJ, Lenglet A, Hill N. Field evaluation of three plant based insect repellent against malaria vector in Vaca Diez Province, the Bolivian Amazon. J Am Mosq Control Assoc. 2002;18(2):107-10.

28. Karunamoorthi K, Husen E. Knowledge and self-reported practice of the local inhabitants on traditional insect repellents in western Hararghe Zone, Ethiopia. Aust J Pharm. 2012;141:212-9.

29. Pålsson K, Jaenson TGT. Comparison of plant products and pyrethroid treated bed nets for protection against mosquitoes (Diptera: Culicidae) in Guinea Bissau, West Africa. J Med Entomol. 1999;36(2):144-8.

30. Seyoum A, Palsson K, Kung'a S, Kabiru EW, Lwande W, Killeen GF, Hassanal A, Knols BG. Traditional use of repellent plants in western Kenya and their evaluation in semi-field experimental huts against Anopheles gambiae, ethnobotanical studies and application by thermal expulsion and direct burning. Trans R Soc Trop Med Hyg. 2002;96:225-31.

31. Youmsi RDF, Fokou PVT, Menkem EZ, Bakarnga-Via I, Keumoe R, Nana V, Boyom FF. Ethnobotanical survey of medicinal plants used as insects repellents in six malaria endemic localities of Cameroon. J Ethnobiol Ethnomed. 2017;13(1):13.

\section{Ready to submit your research? Choose BMC and benefit from:}

- fast, convenient online submission

- thorough peer review by experienced researchers in your field

- rapid publication on acceptance

- support for research data, including large and complex data types

- gold Open Access which fosters wider collaboration and increased citations

- maximum visibility for your research: over $100 \mathrm{M}$ website views per year

At BMC, research is always in progress.

Learn more biomedcentral.com/submissions 